\title{
Data Sharing Statements for Clinical Trials: A Requirement of the International Committee of Medical Journal Editors
}

T he International Committee of Medical Journal Editors (ICMJE) believes there is an ethical obligation to responsibly share data generated by interventional clinical trials because trial participants have put themselves at risk. In January 2016 we published a proposal aimed at helping to create an environment in which the sharing of deidentified individual participant data becomes the norm. In response to our request for feedback we received many comments from individuals and groups (1). Some applauded the proposals while others expressed disappointment they did not more quickly create a commitment to data sharing. Many raised valid concerns regarding the feasibility of the proposed requirements, the necessary resources, the real or perceived risks to trial participants, and the need to protect the interests of patients and researchers.

It is encouraging that data sharing is already occurring in some settings. Over the past year, however, we have learned that the challenges are substantial and the requisite mechanisms are not in place to mandate universal data sharing at this time. Although many issues must be addressed for data sharing to become the norm, we remain committed to this goal.

Therefore, ICMJE will require the following as conditions of consideration for publication of a clinical trial report in our member journals:

1. As of 1 July 2018 manuscripts submitted to ICMJE journals that report the results of clinical trials must contain a data sharing statement as described below.

2. Clinical trials that begin enrolling participants on or after 1 January 2019 must include a data sharing plan in the trial's registration. The ICMJE's policy regarding trial registration is explained at www.icmje .org/recommendations/browse/publishing-and-editorial -issues/clinical-trial-registration.html. If the data sharing plan changes after registration this should be reflected in the statement submitted and published with the manuscript, and updated in the registry record.

Data sharing statements must indicate the following: whether individual deidentified participant data (including data dictionaries) will be shared; what data in particular will be shared; whether additional, related documents will be available (e.g., study protocol, statistical analysis plan, etc.); when the data will become available and for how long; by what access criteria data will be shared (including with whom, for what types of analyses, and by what mechanism). Illustrative exam- ples of data sharing statements that would meet these requirements are in the Table.

These initial requirements do not yet mandate data sharing, but investigators should be aware that editors may take into consideration data sharing statements when making editorial decisions. These minimum requirements are intended to move the research enterprise closer to fulfilling our ethical obligation to participants. Some ICMJE member journals already maintain, or may choose to adopt, more stringent requirements for data sharing.

Sharing clinical trial data is one step in the process articulated by the World Health Organization (WHO) and other professional organizations as best practice for clinical trials: universal prospective registration; public disclosure of results from all clinical trials (including through journal publication); and data sharing. Although universal compliance with the requirement to prospectively register clinical trials has not yet been achieved and requires continued emphasis, we must work toward fulfilling the other steps of best practice as well-including data sharing.

As we move forward into this new norm where data are shared, greater understanding and collaboration among funders, ethics committees, journals, trialists, data analysts, participants, and others will be required. We are currently working with members of the research community to facilitate practical solutions to enable data sharing. The United States Office for Human Research Protections has indicated that provided the appropriate conditions are met by those receiving them, the sharing of deidentified individual participant data from clinical trials does not require separate consent from trial participants (2). Specific elements to enable data sharing statements that meet these requirements have been adopted at ClinicalTrials.gov (https://prsinfo .clinicaltrials.gov/definitions.html\#shareData). The WHO also supports the addition of such elements at the primary registries of the International Clinical Trials Registry Platform. Unresolved issues remain, including appropriate scholarly credit to those who share data, and the resources needed for data access, the transparent processing of data requests, and data archiving. We welcome creative solutions to these problems at www .icmje.org.

We envision a global research community in which sharing deidentified data becomes the norm. Working toward this vision will help maximize the knowledge gained from the efforts and sacrifices of clinical trial participants.

This article was published at Annals.org on 6 June 2017 


\begin{tabular}{|c|c|c|c|c|}
\hline & Example 1 & Example 2 & Example 3 & Example 4 \\
\hline $\begin{array}{l}\text { Will individual participant } \\
\text { data be available } \\
\text { (including data } \\
\text { dictionaries)? }\end{array}$ & Yes & Yes & Yes & No \\
\hline $\begin{array}{l}\text { What data in particular } \\
\text { will be shared? }\end{array}$ & $\begin{array}{l}\text { All of the individual } \\
\text { participant data collected } \\
\text { during the trial, after } \\
\text { deidentification. }\end{array}$ & $\begin{array}{l}\text { Individual participant data } \\
\text { that underlie the results } \\
\text { reported in this article, } \\
\text { after deidentification } \\
\text { (text, tables, figures, } \\
\text { and appendices). }\end{array}$ & $\begin{array}{l}\text { Individual participant data that } \\
\text { underlie the results } \\
\text { reported in this article, after } \\
\text { deidentification (text, tables, } \\
\text { figures, and appendices). }\end{array}$ & Not available \\
\hline $\begin{array}{l}\text { What other documents } \\
\text { will be available? }\end{array}$ & $\begin{array}{l}\text { Study Protocol, Statistical } \\
\text { Analysis Plan, Informed } \\
\text { Consent Form, Clinical } \\
\text { Study Report, Analytic } \\
\text { Code }\end{array}$ & $\begin{array}{l}\text { Study Protocol, Statistical } \\
\text { Analysis Plan, Analytic } \\
\text { Code }\end{array}$ & Study Protocol & Not available \\
\hline $\begin{array}{l}\text { When will data be } \\
\text { available (start and end } \\
\text { dates)? }\end{array}$ & $\begin{array}{l}\text { Immediately following } \\
\text { publication. No end date. }\end{array}$ & $\begin{array}{l}\text { Beginning } 3 \text { months and } \\
\text { ending } 5 \text { years } \\
\text { following article } \\
\text { publication. }\end{array}$ & $\begin{array}{l}\text { Beginning } 9 \text { months and } \\
\text { ending } 36 \text { months following } \\
\text { article publication. }\end{array}$ & Not applicable \\
\hline With whom? & $\begin{array}{l}\text { Anyone who wishes to access } \\
\text { the data. }\end{array}$ & $\begin{array}{l}\text { Researchers who provide } \\
\text { a methodologically } \\
\text { sound proposal. }\end{array}$ & $\begin{array}{l}\text { Investigators whose proposed } \\
\text { use of the data has been } \\
\text { approved by an } \\
\text { independent review } \\
\text { committee ("learned } \\
\text { intermediary") identified for } \\
\text { this purpose. }\end{array}$ & Not applicable \\
\hline $\begin{array}{l}\text { For what types of } \\
\text { analyses? }\end{array}$ & Any purpose. & $\begin{array}{l}\text { To achieve aims in the } \\
\text { approved proposal. }\end{array}$ & $\begin{array}{l}\text { For individual participant data } \\
\text { meta-analysis. }\end{array}$ & Not applicable \\
\hline $\begin{array}{l}\text { By what mechanism will } \\
\text { data be made } \\
\text { available? }\end{array}$ & $\begin{array}{l}\text { Data are available indefinitely } \\
\text { at (Link to be included). }\end{array}$ & $\begin{array}{l}\text { Proposals should be } \\
\text { directed to xxx@yyy. To } \\
\text { gain access, data } \\
\text { requestors will need to } \\
\text { sign a data access } \\
\text { agreement. Data are } \\
\text { available for } 5 \text { years at a } \\
\text { third party website (Link } \\
\text { to be included). }\end{array}$ & $\begin{array}{l}\text { Proposals may be submitted } \\
\text { up to } 36 \text { months following } \\
\text { article publication. After } 36 \\
\text { months the data will be } \\
\text { available in our University's } \\
\text { data warehouse but without } \\
\text { investigator support other } \\
\text { than deposited metadata. } \\
\text { Information regarding } \\
\text { submitting proposals and } \\
\text { accessing data may be } \\
\text { found at (Link to be } \\
\text { provided). }\end{array}$ & Not applicable \\
\hline
\end{tabular}

* These examples are meant to illustrate a range of, but not all, data sharing options.

Darren B. Taichman, MD, PhD, Secretary, ICMJE, Executive Deputy Editor, Annals of Internal Medicine

Peush Sahni, MBBS, MS, PhD, Representative and Past

President, World Association of Medical Editors

Anja Pinborg, MD, Scientific Editor-in-Chief, Ugeskrift for

Laeger (Danish Medical Journal)

Larry Peiperl, MD, Chief Editor, PLOS Medicine

Christine Laine, MD, MPH, Editor-in-Chief, Annals of Internal Medicine

Astrid James, MBBS, Deputy Editor, The Lancet

Sung-Tae Hong, MD, PhD, Editor-in-Chief, Journal of Korean Medical Science

Abraham Haileamlak, MD, Editor-in-Chief, Ethiopian Journal of Health Sciences

Laragh Gollogly, MD, MPH, Editor, Bulletin of the World Health Organization, Coordinator, WHO Press

Fiona Godlee, FRCP, Editor-in-Chief, The BMJ

(British Medical Journal)

Frank A. Frizelle, MBChB, FRACS, Editor-in-Chief,

New Zealand Medical Journal

Fernando Florenzano, MD, Editor, Revista Médica de Chile

(Medical Journal of Chile)
Jeffrey M. Drazen, MD, Editor-in-Chief, New England Journal of Medicine

Howard Bauchner, MD, Editor-in-Chief, JAMA (Journal of the American Medical Association) and the JAMA Network

Christopher Baethge, MD, Chief Scientific Editor, Deutsches Ärzteblatt (German Medical Journal) \& Deutsches

Ärzteblatt International

Joyce Backus, MSLS, Representative and Associate Director for Library Operations, National Library of Medicine

Note: This article is being published simultaneously in Annals of Internal Medicine, BMJ (British Medical Journal), Bulletin of the World Health Organization, Deutsches Ärzteblatt (German Medical Journal), Ethiopian Journal of Health Sciences, JAMA (Journal of the American Medical Association), Journal of Korean Medical Science, New England Journal of Medicine, New Zealand Medical Journal, PLOS Medicine, The Lancet, Revista Médica de Chile (Medical Journal of Chile), and Ugeskrift for Laeger (Danish Medical Journal).

Disclaimer: Dr. Sahni's affiliation as representative and past president of the World Association of Medical Editors (WAME) does not imply endorsement by WAME member journals that are not part of the ICMJE. 
Disclosures: Disclosures can be viewed at www.acponline.org /authors/icmje/ConflictOfInterestForms.do?msNum=M17-1028.

Corresponding Author: Darren B. Taichman, MD, PhD, American College of Physicians, 190 N. Independence Mall West, Philadelphia, PA 19106; e-mail, dtaichman@acponline.org.

Ann Intern Med. doi:10.7326/M17-1028

\section{References}

1. Taichman DB, Backus J, Baethge C, Bauchner H, de Leeuw PW, Drazen JM, et al. Sharing clinical trial data: a proposal from the International Committee of Medical Journal Editors [Editorial]. Ann Intern Med. 2016;164:505-6. [PMID: 26792258] doi:10.7326/M15 $-2928$

2. Menikoff J. Letter from Jerry Menikoff, MD, JD, Director, Office for Human Research Protections, to ICMJE Secretariat. 7 March 2017. Accessed at http://icmje.org/news-and-editorials/menikoff_icmje _questions_20170307.pdf. 